\title{
MICROSTRUCTURAL ANALYSIS AND HIGH-TEMPERATURE STRENGTH OF A DIRECTIONALLY SOLIDIFIED Er2Mo3Si4-MoSi2 EUTECTIC
}

\author{
D. K. Patrick and D. C. Van Aken ${ }^{\dagger}$ \\ Department of Materials Science and Engineering, \\ The University of Michigan, Ann Arbor, MI 48109-2136 \\ tDepartment of Metallurgical Engineering \\ The University of Missouri-Rolla, Rolla, MO 65401-0249 \\ (Received October 29, 1993) \\ (Revised December 21, 1993)

\section{Introduction}

\begin{abstract}
Recent investigations have shown that $\mathrm{Er}_{2} \mathrm{Mo}_{3} \mathrm{Si}_{4}$ is an effective reinforcement for strengthening $\mathrm{MoSi}_{2}[1,2]$. When present in hot-pressed $\mathrm{MoSi}_{2}$ compacts, the $\mathrm{Er}_{2} \mathrm{Mo}_{3} \mathrm{Si}_{4}$ improved both hot hardness and creep resistance of the $\mathrm{MoSi}_{2}$. Creep strengths similar to those reported by Ghosh et al, [3] for MoSi 2 modified with $\mathrm{CaO}$ were observed for these $\mathrm{MoSi}_{2} / \mathrm{Er}_{2} \mathrm{Mo}_{3} \mathrm{Si}_{4} / 20 \mathrm{p}$ (20 vol.\% $\mathrm{Er}_{2} \mathrm{Mo}_{3} \mathrm{Si}_{4}$ particulate) composites [1,2]. The improved creep resistance was attributed to a lower $\mathrm{SiO}_{2}$ content and the presence of hard particles ( $\mathrm{Er}_{2} \mathrm{Mo}_{3} \mathrm{Si}_{4}$ and $\mathrm{Er}_{2} \mathrm{O}_{3}$ ) along $\mathrm{MoSi}_{2}$ grain boundaries that limited grain sliding $[1,2]$. $\mathrm{Er}_{2} \mathrm{O}_{3}$ was formed by the reduction of $\mathrm{SiO}_{2}$ during the processing of the composite. Also noteworthy was that a pseudo-binary eutectic (indicating thermodynamic compatibility) formed between $\mathrm{Er}_{2} \mathrm{Mo}_{3} \mathrm{Si}_{4}$ and $\mathrm{MoSi}_{2}$. An eutectic composition of $\mathrm{Er}_{2} \mathrm{Mo}_{3} \mathrm{Si}_{4}-39 \mathrm{vol}$. \% $\mathrm{MoSi}_{2}$ was determined by quantitative metallography on eutectic cells that formed in arc-melted buttons of $\mathrm{MoSi}_{2}+20$ vol. $\% \mathrm{Er}_{2} \mathrm{Mo}_{3} \mathrm{Si}_{4}$. This eutectic composition was then directionally solidified using the Czochralski method. A small amount of Mo5Si3 was present in these eutectic microstructures which may indicate that an error was associated with the reported eutectic composition or that the eutectic sample used was off stoichiometry. Melting temperatures of $1930 \pm 20^{\circ} \mathrm{C}$ for $\mathrm{Er}_{2} \mathrm{Mo}_{3} \mathrm{Si} 4$ and $1790 \pm 10^{\circ} \mathrm{C}$ for the pseudo-binary eutectic composition were reported [1].
\end{abstract}

The crystal structure of $\mathrm{Er}_{2} \mathrm{Mo}_{3} \mathrm{Si}_{4}$, as reported by Bodak et al. [4], is monoclinic with lattice parameters of $0.667 \mathrm{~nm}, 0.689 \mathrm{~nm}$, and $0.681 \mathrm{~nm}$. The point group and space group of this phase have been identified as $2 / \mathrm{m}$ and $\mathrm{P} 21 / \mathrm{c}$, respectively [5-8]. A theoretical density for $\mathrm{Er}_{2} \mathrm{Mo}_{3} \mathrm{Si}_{4}$ was calculated to be $8.25 \mathrm{~g} / \mathrm{cm}^{3}$ and this compares favorably with other refractory silicide compounds (e.g., Mo5Siz $=8.25 \mathrm{~g} / \mathrm{cm}^{3}$ ). Because of the low crystal symmetry, this intermetallic compound is expected to exhibit limited plasticity, but may possess good high temperature mechanical properties. Mechanical property data on $\mathrm{Er}_{2} \mathrm{Mo}_{3} \mathrm{Si}_{4}$ is still quite limited; however, preliminary creep results from a decremental step-strain rate test show that the directionally solidified (DS) $\mathrm{Er}_{2} \mathrm{Mo}_{3} \mathrm{Si}_{4}$-MoSi2 eutectic has excellent creep resistance at $1300^{\circ} \mathrm{C}$. At this temperature a flow stress of $625 \mathrm{MPa}$ was observed for a strain rate of $5 \times 10^{-5} \mathrm{~s}^{-1}$ ), but failure occurred as the strain rate was reduced to $10^{-5} \mathrm{~s}^{-1}$. In this paper we present further results obtained from constant engineering strain rate compression tests on the same DS eutectic bar.

\section{Experimental Procedures}

Fifteen gram buttons of the eutectic composition were prepared by arc-melting pure elemental materials on a water-cooled copper hearth and in an argon atmosphere. The arc-melted eutectic buttons were then directionally solidified at a pull rate of $45 \mathrm{~mm} / \mathrm{h}$ (Czochralski method) using a tri-arc furnace at McMaster University. Hot hardness tests were performed in vacuum from $23^{\circ} \mathrm{C}$ to $1300^{\circ} \mathrm{C}$ on a Nikon QM2 hot hardness test machine using a Vickers diamond penetrator and a $0.5 \mathrm{~kg}$ load. Rectangular samples measuring approximately $3 \times 3 \times 6 \mathrm{~mm}^{3}$ were sectioned from the DS bars and polished on all sides using 600 grit SiC grinding paper. Compression tests were performed at $1300^{\circ} \mathrm{C}$ and $1400^{\circ} \mathrm{C}$ in a flowing argon atmosphere using an Instron model 4507 twin-screw driven testing machine. All tests were performed at a constant crosshead speed corresponding to an initial strain rate of $5 \times 10^{-5} \mathrm{~s}^{-1}$. The loading direction was parallel to the eutectic growth direction.

Volume fraction analysis of the $\mathrm{Er}_{2} \mathrm{Mo}_{3} \mathrm{Si}_{4}, \mathrm{MoSi}_{2}$, and $\mathrm{Mo}_{5} \mathrm{Si}_{3}$ was performed using the point grid method on metallographically prepared sections cut transverse to the eutectic growth direction. Reported uncertainties represent a $95 \%$ confidence limit and were calculated as 


$$
2\left[\left\{P_{f}-\left(1-P_{f}\right)\right\} / P_{t o t}\right]^{1 / 2}
$$

where $P_{f}$ is the average point fraction and $P_{t o t}$ is the total number of grid points applied [9].

\section{Results and Discussion}

Microstructures of the arc-melted buttons and the directionally solidified eutectic are shown in Fig. 1. Highly faceted $\mathrm{Mos}_{5} \mathrm{Si}_{3}$ cells were observed in both the arc-melted and the DS materials (see Fig. 1a) and the varying orientation of the script-lamellar microstructure next to the $\mathrm{M}_{5} \mathrm{Si}_{3}$ suggests that the $\mathrm{M}_{5} \mathrm{Si}$ i3 solidified first since the script-lamellar structure within the cell does not, in most cases, match that of the exterior. Mo5Si3 was not observed in the interior or exterior script-lamellar structure near these cells; however, in areas far from the Mo5Si3 cells small cuboidal particles of $\mathrm{Mos}_{5} \mathrm{Si}_{3}(10 \mu \mathrm{m}$ in size) were observed (see Fig. 1b). A volume fraction analysis of the DS eutectic bar indicated a composition of $40 \pm 4.8 \mathrm{vol} \% \mathrm{MoSi}_{2}$ and $2.9 \pm 1.6 \mathrm{vol} \% \mathrm{MosSi}$ with the balance being $\mathrm{Er}_{2} \mathrm{Mo}_{3} \mathrm{Si}_{4}$. Based upon this microstructural analysis we believe that the eutectic composition of the test bar was molybdenum rich and that some silicon may have been lost during arc-melting. Presence of $\mathrm{Mos}_{5} \mathrm{Si}_{3}$ in these microstructures also suggests that a ternary phase eutectic may exist between $\mathrm{Er}_{2} \mathrm{Mo}_{3} \mathrm{Si}_{4}, \mathrm{MoSi}_{2}$, and $\mathrm{Mos}_{3} \mathrm{Si}_{3}$. Transverse and longitudinal sections of the DS eutectic bar are shown in Figs. $1 \mathrm{~b}$ and $1 \mathrm{c}$. Both micro- and macrocracks were evident throughout the DS bar with cracks running both parallel and perpendicular to the growth direction (see Fig. 1d). The extensive cracking is believed to be related to thermal stresses generated by a difference in thermal contraction between $\mathrm{Er}_{2} \mathrm{Mo}_{3} \mathrm{Si}_{4}$ and $\mathrm{MoSi}_{2}$ as the material cooled after solidification.

Engineering stress-strain curves from compression tests conducted at $1300^{\circ} \mathrm{C}$ and $1400^{\circ} \mathrm{C}$ are shown in Fig. 2 . The strengths reported here are believed to be lower than the actual strength of the material since each sample contained a significant number of internal cracks. Failure was generally initiated by longitudinal cracking followed by sample buckling. At these temperatures the $\mathrm{MoSi}_{2}$ behaved in a ductile manner and served as a toughening agent for the $\mathrm{Er}_{2} \mathrm{Mo}_{3} \mathrm{Si}_{4}$. Results shown in Fig. 2a are those first reported by the authors in Ref. 1 . In the present study, a second test was performed at $1300^{\circ} \mathrm{C}$ (see Fig. $2 \mathrm{~b}$ ) and a maximum stress of $540 \mathrm{MPa}$ was observed prior to failure of the sample by longitudinal cracking (see Fig. 3). It is interesting to note, however, that this sample failed in a graceful manner and was able to maintain a load of over $890 \mathrm{~N}(200 \mathrm{lbs})$ while the sample buckled. At $1400^{\circ} \mathrm{C}$, lower strengths of $240 \mathrm{MPa}$ and $450 \mathrm{MPa}$ were observed (see Figs. $2 \mathrm{c}$ and $2 \mathrm{~d}$ ). Again, failure was initiated by longitudinal cracking and sample buckling. We believe that the value of $450 \mathrm{MPa}$ is closer to the true strength at $1400^{\circ} \mathrm{C}$ and that the first sample failed prematurely as a result of the internal microcracks.

Hot hardness results for monolithic $\mathrm{Er}_{2} \mathrm{Mo}_{3} \mathrm{Si}_{4}$ and the DS eutectic are shown in Fig. 4 and compared with reported results for hot pressed $\mathrm{MoSi}_{2}$ powder [10]. The hardness of $\mathrm{Er}_{2} \mathrm{Mon}_{3} \mathrm{Si}_{4}$ drops slightly from about $9 \mathrm{GPa}$ at room temperature to $5.8 \mathrm{GPa}$ at $1300^{\circ} \mathrm{C}$. The DS eutectic also retains a hardness of $6.6 \mathrm{GPa}$ at $1100^{\circ} \mathrm{C}$ and then drops to about $4 \mathrm{GPa}$ at $1300^{\circ} \mathrm{C}$ as compared to $1.5 \mathrm{GPa}$ for the $\mathrm{MoSi}_{2}$. Extensive cracking in the $\mathrm{Er}_{2} \mathrm{Mo}_{3} \mathrm{Si}_{4}$ was observed around each indent indicating very limited plasticity for this phase between room temperature and $1300^{\circ} \mathrm{C}$.

\section{Summary}

The observed flow stress values are well above those reported for other $\mathrm{MoSi}_{2}$ based materials and the high strength of the eutectic must be attributed to the $\mathrm{Er}_{2} \mathrm{Moz}_{3} \mathrm{Si}_{4}$ phase. The compression strength is believed to be at least $625 \mathrm{MPa}$ at $1300^{\circ} \mathrm{C}$ and at least $450 \mathrm{MPa}$ at $1400^{\circ} \mathrm{C}$. The values reported here represent lower bounds on the strength since sample buckling was the predominate failure mode. In this study, $\mathrm{MoSi}_{2}$ acted as a ductile phase and the eutectic failed in a graceful manner. Elimination of the thermal cracks would greatly improve the mechanical properties of this eutectic. Internal cracking could be reduced by either using a lower thermal gradient during solidification processing or hot isostatic pressing the as-solidified eutectic, or both.

\section{Acknowledgements}

The authors wish to express their thanks to Mr. Jim Garrett of McMaster University, Hamilton, Ontario, Canada for providing the directionally solidified material used in this study. This research was supported by NSF Grant No. MSM 86-57581.

\section{References}

1. D.K. Patrick and D.C. Van Aken, High Temperature Ordered Intermetallic Alloys V, Eds. I. Baker, J.D. Whittenberger, R. Darolia, and M.H. Yoo, Mat. Res. Soc. Sym. Proc. 288, Pittsburgh, PA, 1135-1141 (1993).

2. D.K. Patrick, M.S. Thesis, The University of Michigan 1993. 
3. A.K. Ghosh, A. Basu, and H. Kung, Intermetallic Matrix Composites II, Eds. D.B. Miracle, D.L. Anton, and J.A. Graves, Mat. Res. Soc.Sym. Proc. 273, Pittsburgh, PA, 259-266 (1992).

4. O.I. Bodak, Yu. K. Gorelenko, V.I. Yarovets, and R.v. Skolozdra, Izvestiya AkademII Nauk SSSR, Neorgan Icheskie Materialy 20 (5), 741 (1984).

5. D.P. Mason, D.C. Van Aken, and J.F. Mansfield, Intermetallic Matrix Composites II, Eds. D.B. Miracle, D.L. Anton, and J.A. Graves, Mat. Res. Soc.Sym. Proc.273, Pittsburgh, PA, 289-294 (1992).

6. P. Villars and L.D. Calvert, Pearson Handbook of Crystallography Data for Intermetallic Phases, 2nd Ed., Vol.3, ASM Intemational, 3130 (1991).

7. J.L.C. Daams, P. Villars, and J.H.N. van Vucht, Atlas of Crystal Structure Types for Intermetallic Phases, ASM International, 319 (1991).

8. Intemational Tables for Crystallography, Vol. A, Ed. by T. Hahn, D. Reidel Publishing Co., Holland, 174 (1983).

9. J.E. Hilliard and J.W. Cahn, Trans. TMS-AMM 221, 344 (1961).

10. S. Maloy, A.H. Heuer, J. Lewandowski, and J. Petrovic, J. Amer. Cer. Soc. 74, N10, 2704-2706 (1991).
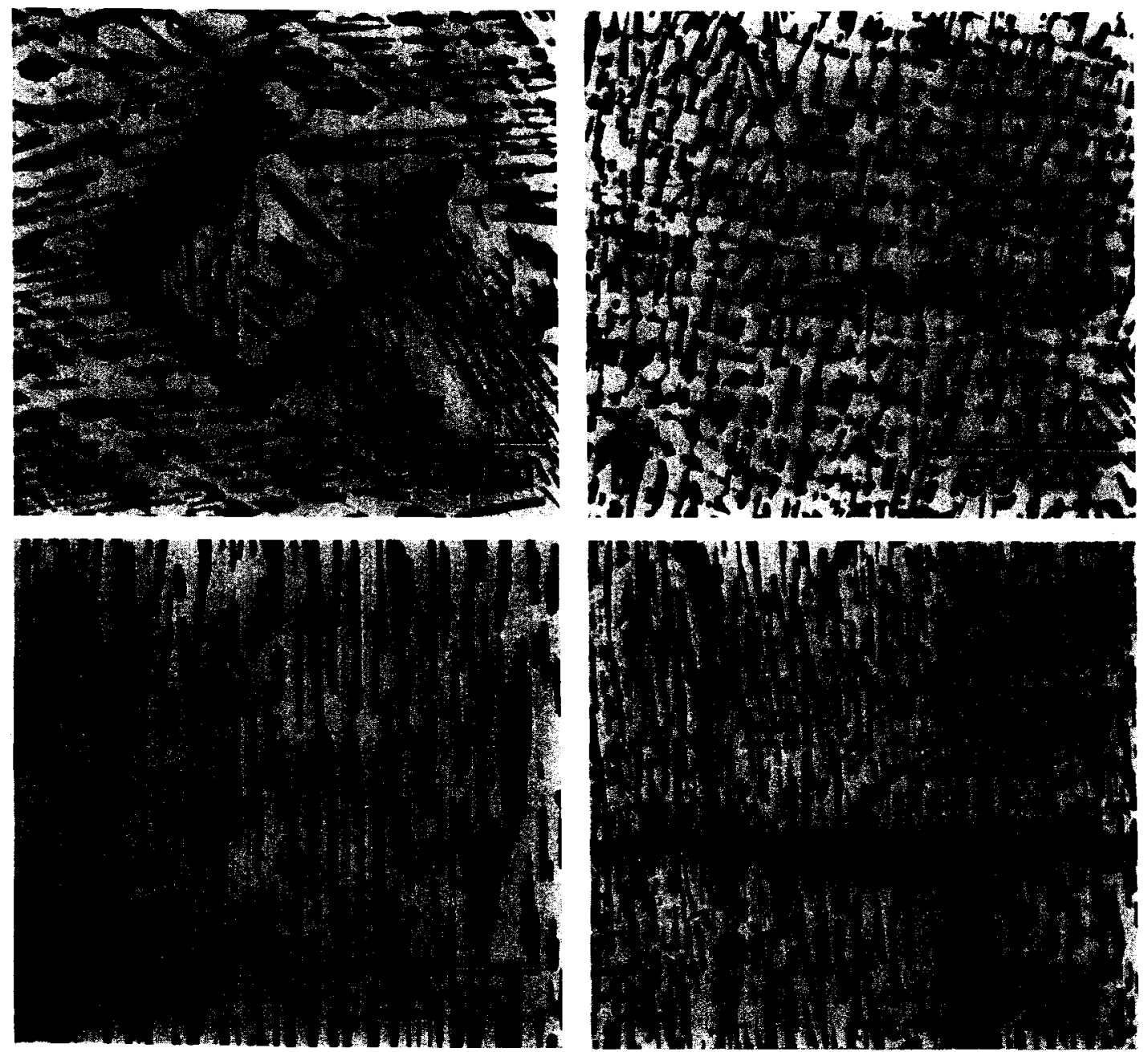

FIG. 1: Backscattered electron images of the $\mathrm{Er}_{2} \mathrm{Mo}_{3} \mathrm{Si}_{4}-\mathrm{MoSi}_{2}$ eutectic. Phases are identified as follows: $\mathrm{A}-\mathrm{MoSi}_{2}$, $\mathrm{B}-\mathrm{Er}_{2} \mathrm{Mo}_{3} \mathrm{Si}_{4}$, and $\mathrm{C}-\mathrm{Mos}_{5} \mathrm{Si}_{3}$. (a) Microstructure of an arc-melted eutectic button showing the faceted Mo5 $\mathrm{Si}_{3}$ cells. The image is transverse to the growth direction. (b) Transverse and (c) longitudinal cross-sections of the DS eutectic bar. (d) Cracks were observed throughout the DS eutectic bar running both parallel and perpendicular to the eutectic growth direction. Samples for compression tests were cut from sections of the bar where cracking was minimal; however, microcracking was prevalent in all of the samples examined. 


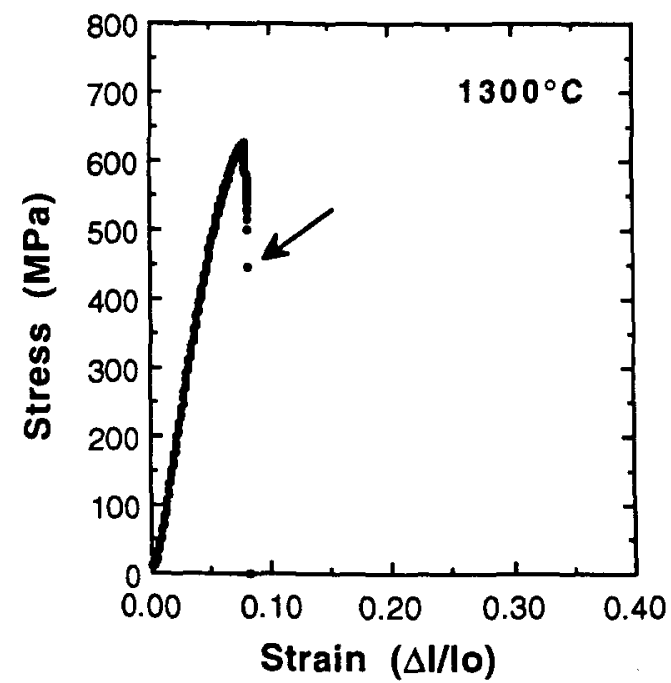

(a)

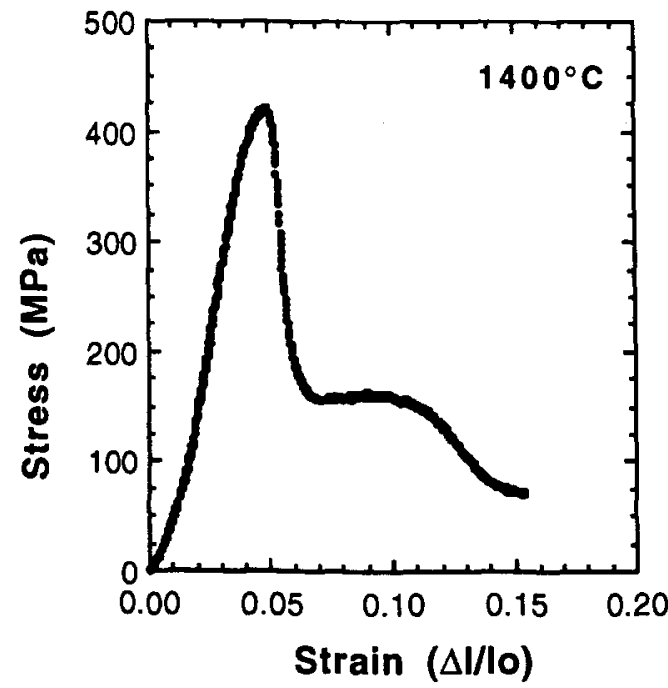

(c)

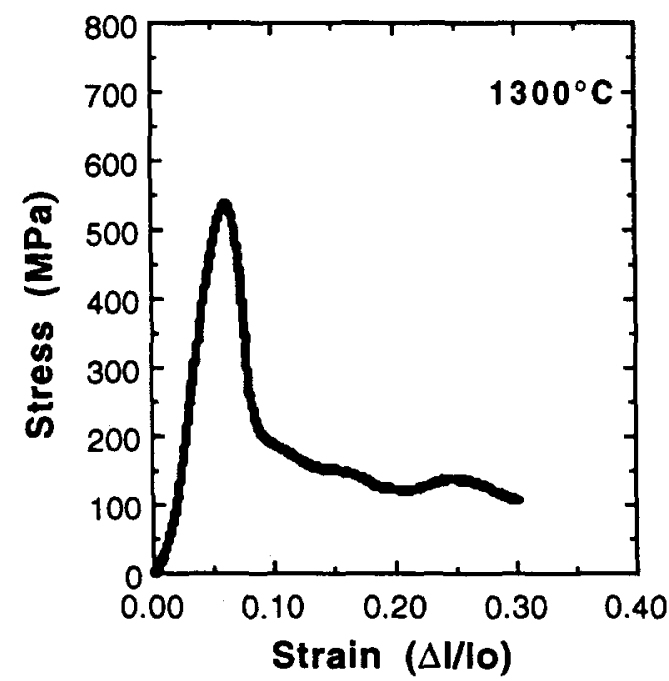

(b)

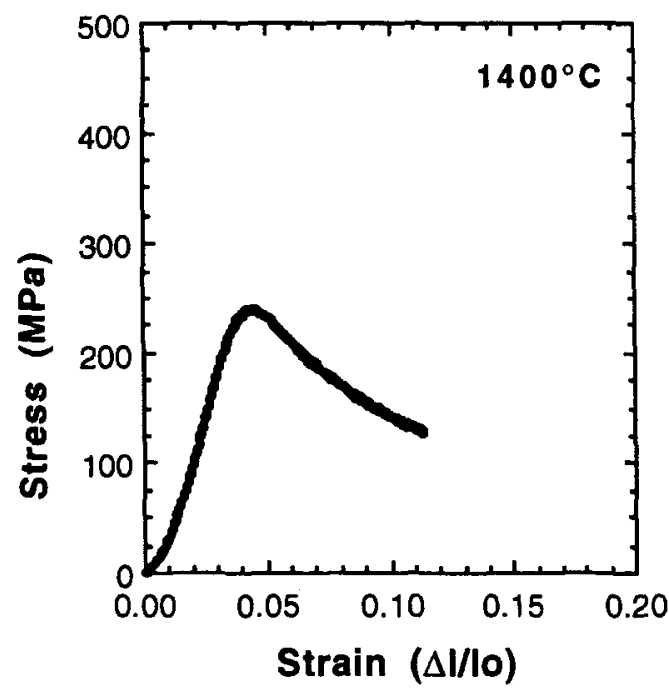

(d)

FIG. 2: Engineering stress-strain curves for the compression tests conducted at $1300^{\circ} \mathrm{C}$ and $1400^{\circ} \mathrm{C}$. Data in (a) was generated as the first part of a decremental step-strain rate test at $1300^{\circ} \mathrm{C}$ under a constant engineering strain rate of $5 \times 10^{-5} \mathrm{~s}^{-1}$. The strain rate was reduced prior to reaching a steady state flow stress to avoid brinelling the sample platens. An arrow indicates when the sample failed and when the test was terminated. All other tests were conducted at a constant engineering strain rate of $5 \times 10^{-5} \mathrm{~s}^{-1}$. 


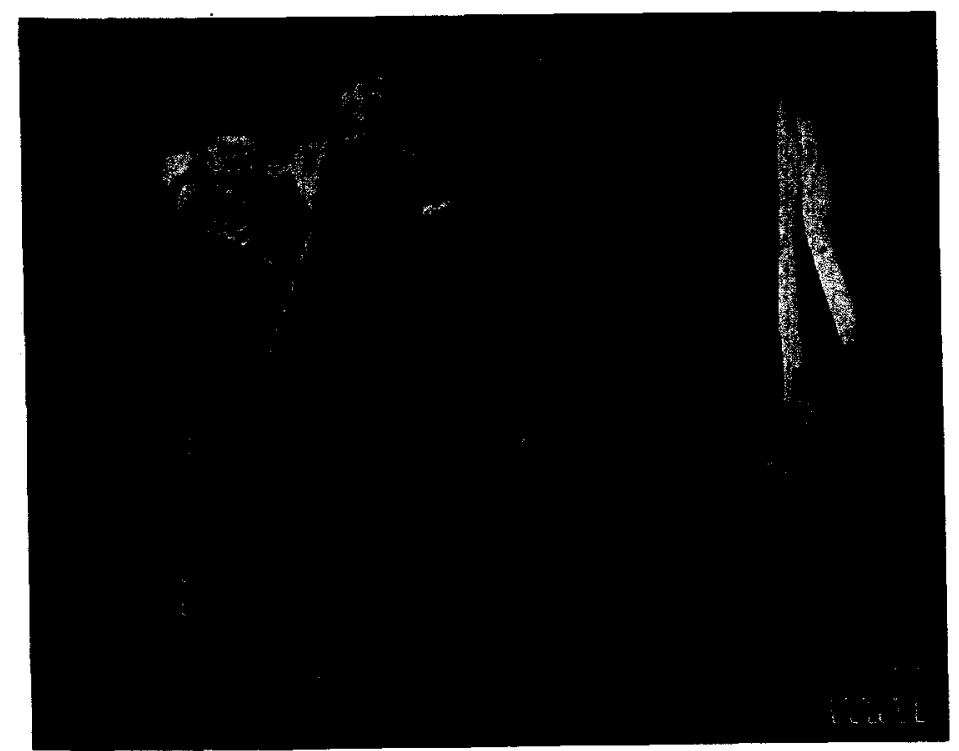

FIG. 3: A secondary electron image of the fractured sample compressed at $1300^{\circ} \mathrm{C}$ (see Fig. 2b). The sample failed in a graceful manner and was still able to support $890 \mathrm{~N}$ ( $200 \mathrm{lbs})$ when the test was terminated.

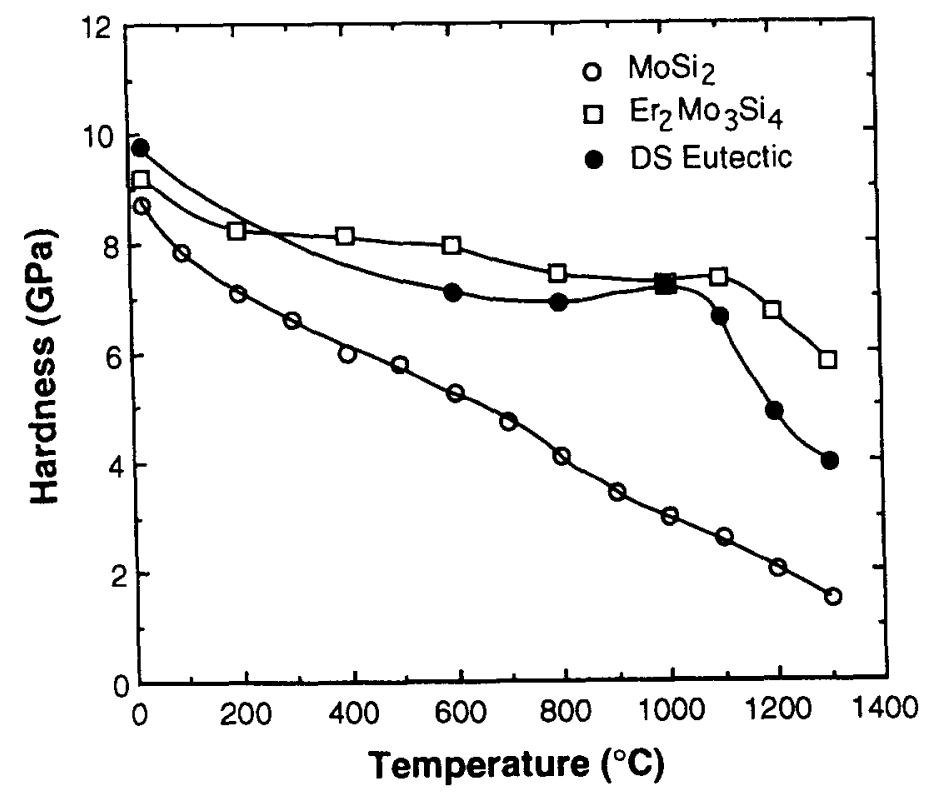

FIG. 4: Hot hardness test results for powder-processed $\mathrm{MoSi}_{2}$ [from Ref. 10], arc-melted $\mathrm{Er}_{2} \mathrm{Mo}_{3} \mathrm{Si}_{4}$, and the DS eutectic. 